\title{
MAPPING OF SALTWATER INTRUSION AT IGBOKODA, SOUTHWESTERN, NIGERIA USING COMBINED GEOPHYSICAL AND CHEMICAL TECHNIQUES
}

\author{
JAMES ADEGOKE $^{1}$, WILFRED IGBOAMA ${ }^{* 2}$, EMMANUEL ADETUWO ${ }^{1}$ \\ ${ }^{1}$ Department of Physics, University of Ibadan, Ibadan, Nigeria \\ ${ }^{2}$ Department of Physics, Federal University, Oye-Ekiti, Nigeria
}

\begin{abstract}
This research work was set out to map saltwater intrusion in Igbokoda area of Ilaje, Ondo State, Southwestern, Nigeria using combined geophysical and chemical techniques. Eight (8) Vertical Electrical sounding were carried out using the Schlumberger Electrode array system with maximum spread of $(\mathrm{AB} / 2) 133 \mathrm{~m}$ and water samples were acquired and analysed using atomic absorption spectrometer. The VES data was interpreted by the method of partial curve matching and computer iteration technique using Winresist software. The result obtained revealed four geoelectric layers. The saltwater intrusion originated from movement of seawater into the freshwater aquifer coupled with human activities.
\end{abstract}

Keywords: geophysical, Igbokoda, intrusion, saltwater, Vertical Electrical Sounding (VES)

\section{INTRODUCTION}

Groundwater are found underground in cracks and spaces in soil, sand and rocks. The area where water fills these spaces is the saturated zone. The top of this zone is the water table and it may be only a foot below the ground's surface or it may be hundreds of feet down [1]. Groundwater can be found almost everywhere. Groundwater is stored in - and moves slowly through - layers of soil, sand and rocks called aquifers [1].

Groundwater constitutes over $90 \%$ of the world's readily available freshwater resources on the earth while the remaining $10 \%$ are in lakes, reservoirs, rivers and wetlands. The quality and availability of these fresh groundwater resources in coastal areas are hampered by seawater intrusion from the seaside. This is a natural process, by which seawater displaces and mixes with the fresh groundwater in coastal aquifers due to the density difference existing between waters of different salinities. Saltwater intrusion i.e. the displacement of fresh groundwater by groundwater with a higher salinity has become an accepted scientific term in the research field [2].

Climatic variables, such as precipitation, surface runoff, temperature play a role in affecting saltwater intrusion. With lower precipitation and warmer temperatures, the recharge rate will be much less due to lack of groundwater present and increased evaporation [3]. Along with this, other factors may influence the groundwater recharge rate indirectly. An example is the rising carbon dioxide emissions in the atmosphere [3].

A considerable amount of research has been published regarding the use of geophysical and chemical methods to investigate and map out saltwater impacted zone in groundwater aquifer. Reilly made a comprehensive review of

\footnotetext{
* Corresponding author, email wnigboama@gmail.com

(c) 2018 Alma Mater Publishing House
} 
various studies relating to saltwater intrusion [4]. Glover developed a formula to describe the saltwaterfreshwater 'sharp' interface in a coastal aquifer using potential theory. Problems related to environmental studies, particularly in terms of contamination of subsurface soil and groundwater and aquifer vulnerability have been solved using Electrical methods [5, 6, 7, 8, 9, 10, 11].

Igbokoda coastal aquifers experienced an intensive saltwater intrusion caused by both natural and human induced processes. Available reports have shown that there are abandoned boreholes, in the study area. This is due to salt water intrusion into the freshwater aquifer. Hence this study is aimed at mapping out saltwater intrusion at Igbokoda by combining geophysical and geochemical techniques. Management of coastal water resources, is therefore important due to saline intrusion, hence the purpose and the importance of this study is not in preventing salt water intrusion but in revealing the present state of the saltwater intrusion in the area.

\section{SITE DESCRIPTION AND GEOLOGY OF THE AREA}

The study area lies within Dahomey basin covering mainly Igbokoda and its environment. It is situated between latitude $6^{\circ} 10^{\prime \prime}$ to $6^{\circ} 25^{\prime \prime} \mathrm{N}$ and longitude $4^{\circ} 39^{\prime \prime}$ to $4^{\circ} 53^{\prime \prime}$ E covering the coastal sand bars that stretch in a NW - SE direction from Okitipupa to the Atlantic Ocean.

The area is covered mainly by Quaternary alluvium deposits underlain virtually in all places by the Quaternary coastal plain sands (Figure 1). The coastal plain sands constitute the major shallow hydrogeological units and adequate annual recharge is guaranteed considering the high annual rainfall and other favourable climatic conditions. Major rocks types found in the area are migmatite, gneiss, older granite and pegmatite; which were formed during late phase crystallization of granite magma. Dendritic drainage pattern characterizes the study area. The area are heavily disserted by rivers. In the Northern part, the drainage pattern is Trellis, while coming to the southern part of the area, the drainage pattern charges to dendritic, but on the whole dendritic pattern is more pronounced.

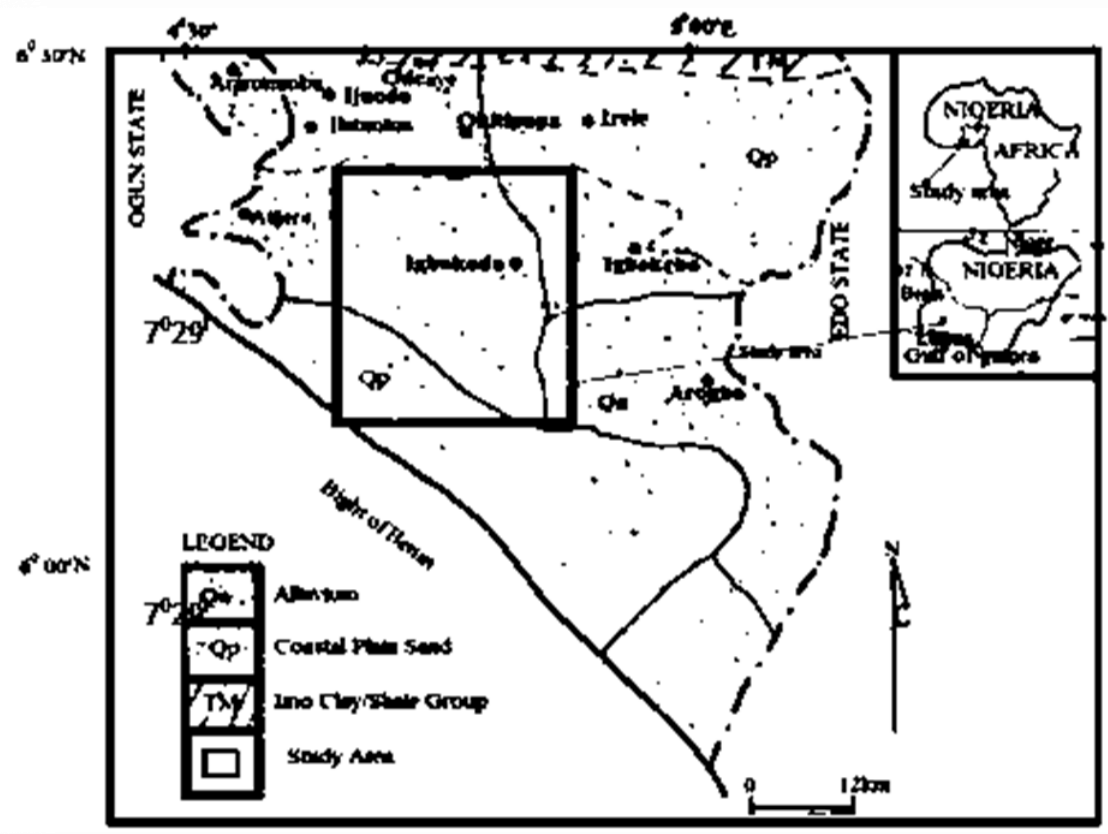

Fig. 1. Geological map of the Study area (modified after Talabi, 2012) [12].

The study area falls under an unconventional climate region called sub-equatorial south. It has characteristically two climate seasons, which are the wet and dry seasons. It has a mean annual rainfall of $1500 \mathrm{~mm}$, average temperature of $27^{\circ} \mathrm{C}$ and also the mean annual relative humility of above $80 \%$ (Figure 2). 


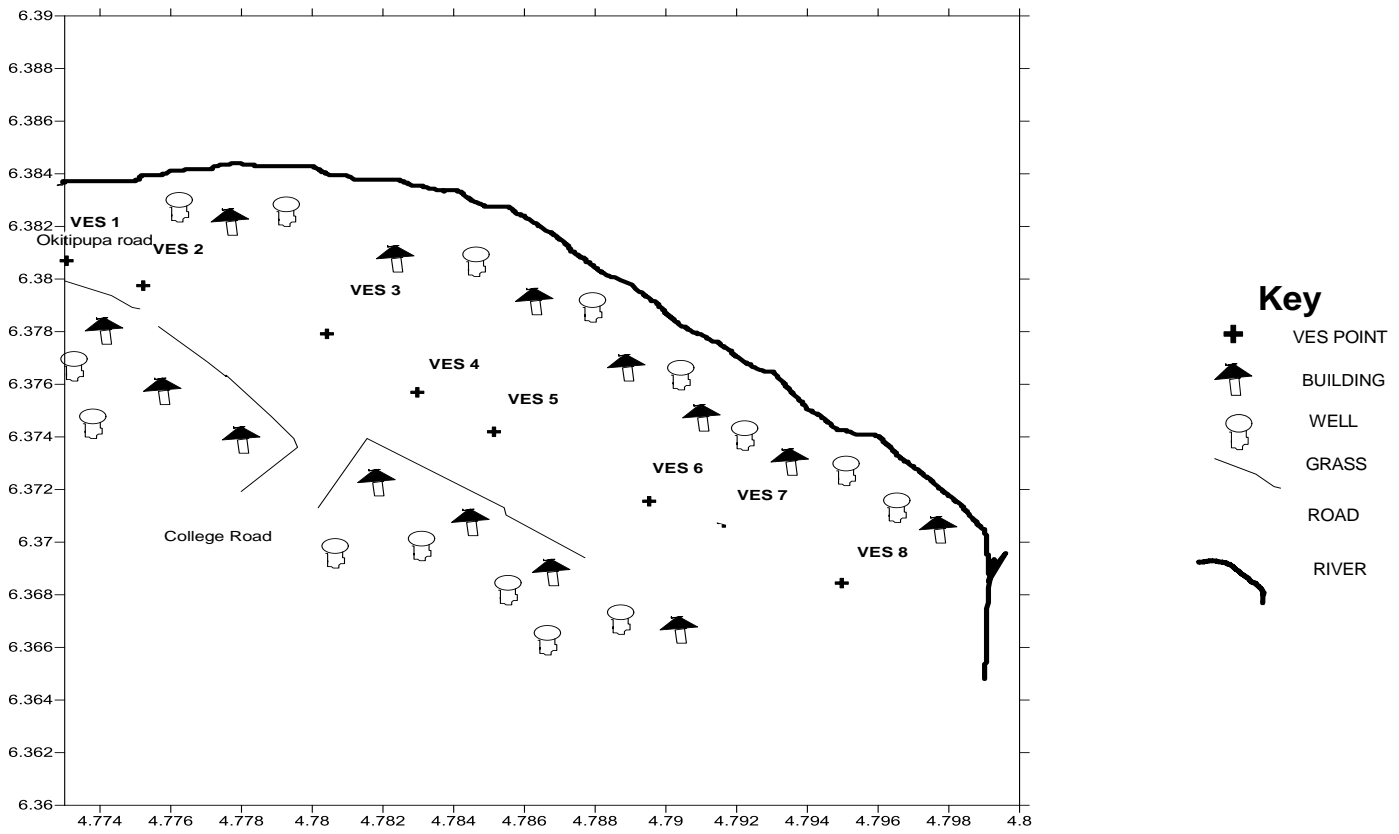

Fig. 2. Schematic Base map of the Study area.

The study area falls within the Basement Complex of Southwestern Nigeria [13]. [14] has divided the Basement Complex of Nigeria into six major groups as follows: Migmatite-gneiss-quartzite complex (Oldest); Schist belt; Charnockitic:- gabbroic and doleritic rocks; Older Granites; Metamorphosed to un-metamorphosed calc-alkaline volcanic and hyperbyssal rocks; and; Unmetamorphosed dolerites, basic and syenitedykes (Youngest).

\section{MATERIALS AND METHODS}

\subsection{Vertical electrical sounding (VES)}

The Vertical electrical sounding employing a Schlumberger configuration was conducted in the area using resistivity meter, Geopulse Tiger Meter and GPS. Direct current was injected into the ground through a pair of current electrodes. The resistivity meter measured the current that was passed into the ground and the potential difference across the potential electrodes was measured by direct current voltmeter of high input impedance. Measurements were performed with a maximum electrode spread (AB/2) of $133 \mathrm{~m}$, and a total of eight (8) VES was carried out starting from landward to seaward.

\subsection{Water samples collection and preparation}

Water samples were collected into $1 \mathrm{~L}$ high density polyethylene (HDPE) plastic vials pre-treated with $4 \mathrm{M}$ $\mathrm{HNO}_{3}$ and properly rinsed with de-ionized water followed by doubly distilled water before use. Atomic absorption spectrometry was done using the atomic absorption spectrometer.

\subsection{Data acquisition and integrated interpretation}

The schlumberger VES curves were initially interpreted by master curves. These processes provide the estimates of resistivities and thickness of various geoelectric layers. The resistivities and thickness were used as starting models for the computer iteration. To obtain an acceptable agreement, the differences between the observed and calculated data were minimized [15]. This difference is expressed as the root-mean-square error (RMS \%).

Partial curve matching technique was employed for quantitative interpretation of the sounding data [16] and finally the iteration [17]. For the iterative resistivity sounding interpretation, the WinRESIST Version 1.0 software was used. The Golden SURFER 9.9.785 was used to produce all the relevant hydro-resistivity maps of the study area. 


\section{RESULTS AND DISCUSSIONS}

\subsection{Depth Sounding Curve Types}

The various curve types show the qualitative interpretation of the VES data, two curve types were identified within the study area (Table 1):

1. KH-Type curve: This curve represents geoelectric lithologies with layer resistivity showing the following format $\rho_{1}<\rho_{2}>\rho_{3}<\rho_{4}$.

2. K-Type curve: This curve represents geoelectric lithologies with layer resistivity showing the following format $\rho_{1}<\rho_{2}>\rho_{3}$.

It could be observed that the KH-type curve is the most dominant (Figure 3); accounting for $62 \%$, which may typify a rapid resistivity progression possibilities indicative of shallow, resistive bedrock, while type $\mathrm{K}$ accounting for $38 \%$ of the curve type, indicative of shallow, resistive bedrock often associated with groundwater. Approximately $62 \%$ of the soundings are 4-layered that is KH-types while $38 \%$ also are 3layered, that is K type curves (Figure 4).

Table 1.The results of Interpreted VES Curves.

\begin{tabular}{|c|c|c|c|c|c|}
\hline $\begin{array}{c}\text { VES } \\
\text { Station }\end{array}$ & Curve Types & $\begin{array}{c}\text { Apparent } \\
\text { Resistivity }(\Omega \mathrm{m})\end{array}$ & $\begin{array}{l}\text { Thickness } \\
\text { (m) }\end{array}$ & $\begin{array}{l}\text { Depth } \\
\text { (m) }\end{array}$ & Layer Description \\
\hline \multirow[t]{4}{*}{1} & KH & 68 & 0.6 & 0.6 & Top soil \\
\hline & & 1912 & 2.1 & 2.7 & Weathered Layer \\
\hline & & 129 & 31.9 & 34.6 & Fractured layer \\
\hline & & 9235 & - & & Fresh Basement \\
\hline \multirow[t]{4}{*}{2} & $\mathrm{KH}$ & 314 & 0.8 & 0.8 & Top soil \\
\hline & & 1622 & 13.2 & 14 & Weathered Layer \\
\hline & & 288 & 13.7 & 27.7 & Fractured Basement \\
\hline & & 1050 & - & & Fresh Basement \\
\hline \multirow[t]{4}{*}{3} & $\mathrm{KH}$ & 264 & 2.3 & 2.3 & Top soil \\
\hline & & 1901 & 7.3 & 9.6 & Weathered Layer \\
\hline & & 54 & 27.4 & 37.0 & Fractured Basement \\
\hline & & 3255 & - & - & Fresh Basement \\
\hline \multirow[t]{4}{*}{4} & $\mathrm{KH}$ & 70 & 0.5 & 0.5 & Top soil \\
\hline & & 1313 & 8.6 & 9.1 & Weathered layer \\
\hline & & 49 & 24.0 & 33.1 & Fractured Basement \\
\hline & & 218 & - & - & Fresh Basement \\
\hline \multirow[t]{4}{*}{5} & KH & 189 & 0.9 & 0.9 & Top soil \\
\hline & & 624 & 18.4 & 19.3 & Weathered layer \\
\hline & & 28 & 9.8 & 29.1 & Fractured Basement \\
\hline & & 38 & - & - & Fractured Basement \\
\hline \multirow[t]{3}{*}{6} & $\mathrm{~K}$ & 134 & 0.6 & 0.6 & Top soil \\
\hline & & 370 & 13.3 & 13.9 & Fractured Basement \\
\hline & & 25 & - & - & Fractured Basement \\
\hline \multirow[t]{3}{*}{7} & $\mathrm{~K}$ & 110 & 0.4 & 0.4 & Top soil \\
\hline & & 526 & 15.7 & 16.1 & Weathered layer \\
\hline & & 13 & & & Fractured Basement \\
\hline \multirow[t]{3}{*}{8} & $\mathrm{~K}$ & 179 & 0.3 & 0.3 & Top soil \\
\hline & & 491 & 12.3 & 12.6 & Weathered layer \\
\hline & & 12 & - & - & Fractured Basement \\
\hline
\end{tabular}



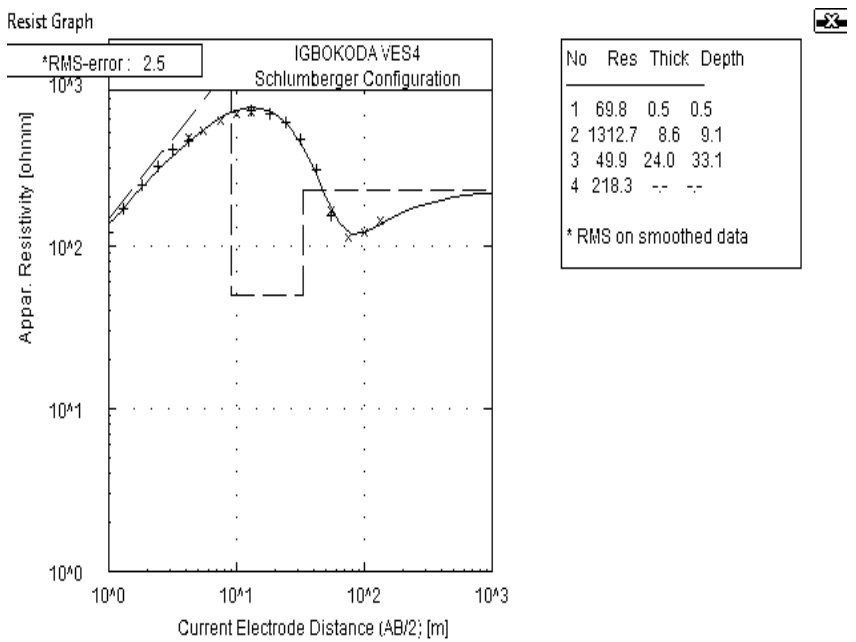

Fig. 3. Typical KH Curve Type (VES 4).
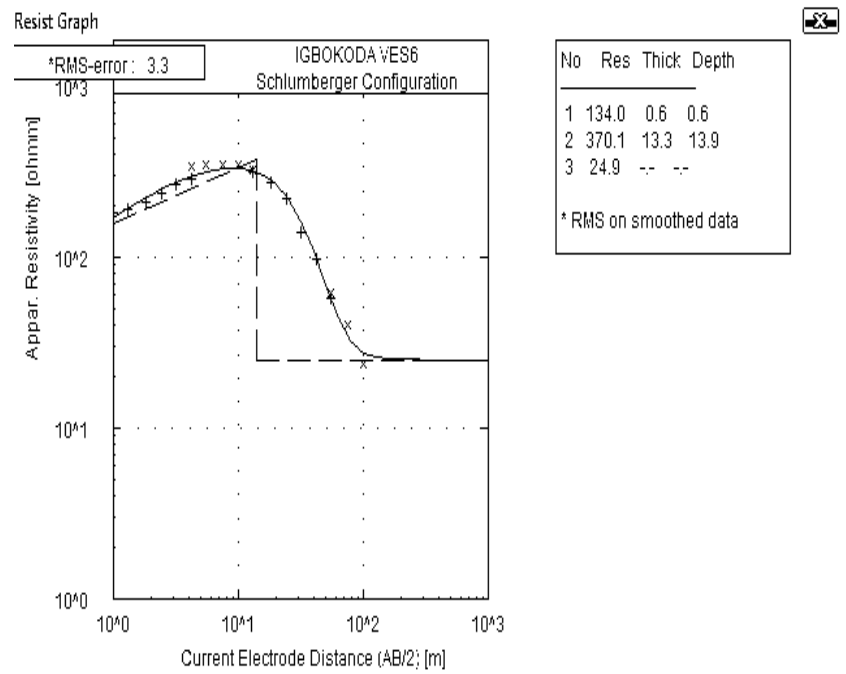

Fig. 4. Typical K curve type.

\subsection{Geo-electric Sections}

Four major geoelectric layers were delineated within the study area which includes: the topsoil, the weathered layer, fractured basement and the fresh basement rock (Figures 5 and 6). The resistivity of the first layer (topsoil) ranged from $68 \Omega \mathrm{m}$ to $314 \Omega \mathrm{m}$ and thickness ranged from $(0.3 \mathrm{~m}$ to $2.3 \mathrm{~m})$. The topsoil is composed of sandy soil, the resistivity of the underlying layer, (weathered layer) ranged from (491 $\Omega \mathrm{m}$ to $9235 \Omega \mathrm{m}$ ) with thickness values varying between $(2.7 \mathrm{~m}$ to $19.3 \mathrm{~m})$. It is composed of sandy soil. The weathered layer is underlain by the fresh basement but showed fractures in some areas. The resistivity of the fractured zones varies between $(12 \Omega \mathrm{m}$ to $370 \Omega \mathrm{m})$ and the thickness ranged from $(0.4 \mathrm{~m}$ to $37.1 \mathrm{~m})$. The presence of a low resistivity zone as depicted by the geoelectric sections is the main characteristic of the resistivity survey. The subsurface within this area of predominantly low resistivity structure is reflective of saline water incursion in to the aquifer [18].

This is considered to be associated to the seawater intrusion [19]. The geoelectric sections showed that the overburden is generally thin. The hydrogeological significance of the study area is enhanced by the fractured basement which is identified in few places and is of no appreciable thickness. The thin nature of the various layers that made up the overburden and its resistivity indicated high porosity and suggests that the aquifer in the area is prone (vulnerable) to contamination and could permit easy flow of seawater to the freshwater aquifer. 

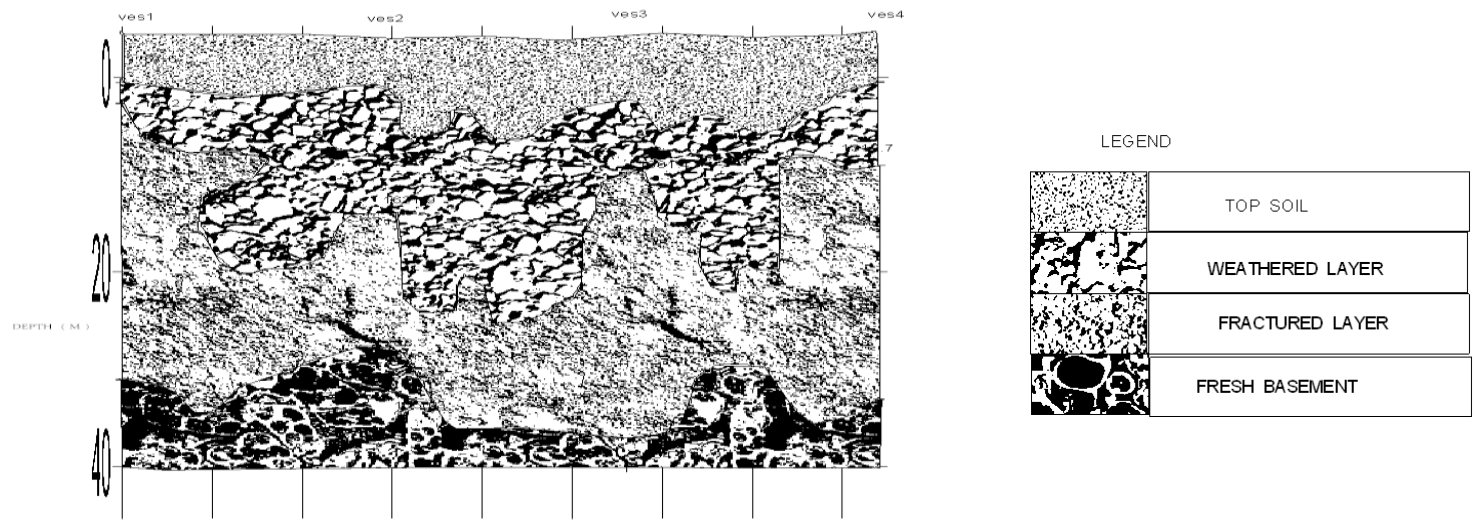

Fig. 5. A geoelectric section obtained from VES1-VES4 (Resistivity values in $\Omega \mathrm{m}$ ).
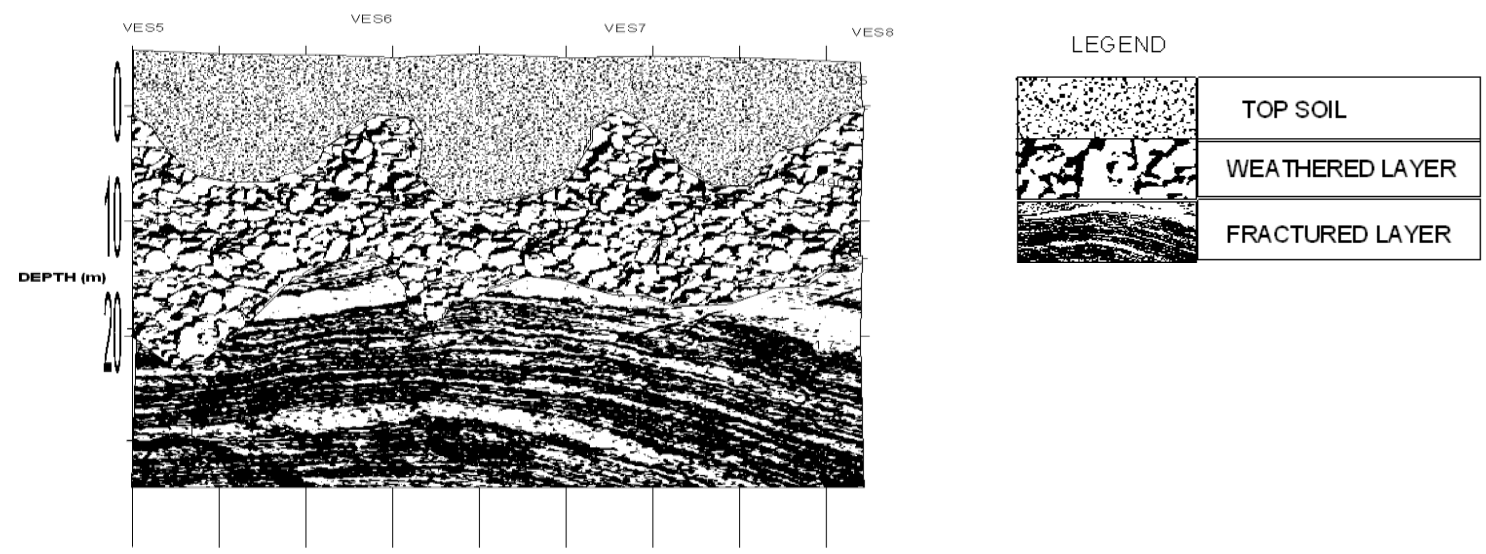

Fig. 6. A geoelectric section obtained from VES5-VES8 (Resistivity values in $\Omega \mathrm{m}$ ).

\subsection{Iso-resistivity map of the topsoil}

The isoresistivity map of the topsoil in Igbokoda area of Ilaje is shown in Figure 7. This map showed the variation in the resistivity of the topsoil within the study area. It shows that the topsoil resistivity varies from 68 $\Omega \mathrm{m}$ to less than $320 \Omega \mathrm{m}$ (which is typical of hard-pan laterite and basement).

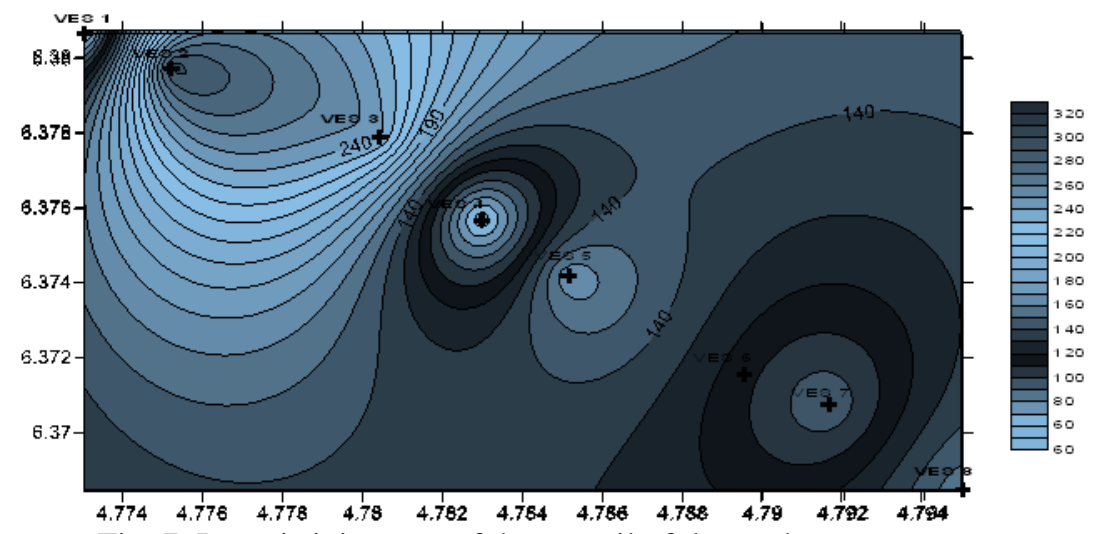

Fig. 7. Isoresistivity map of the topsoil of the study area.

\subsection{Isopach map of the topsoil}

This map showed the variation in the thickness of the topsoil within the study area (Figure 8). It showed that the thickness of the topsoil varies from $0.2 \mathrm{~m}$ to $2.3 \mathrm{~m}$. This generally indicates that the topsoil in the area rarely goes beyond $2 \mathrm{~m}$ thickness. This thin nature of the topsoil would possibly expose the area to chemical contaminants. 


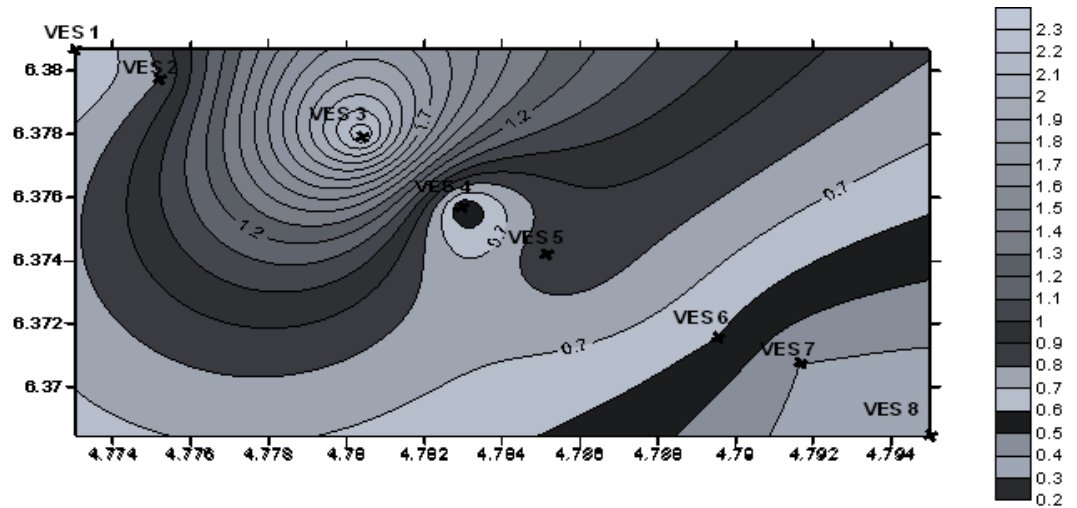

Fig. 8. Isopach map of topsoil of the study area.

\subsection{Iso-resistivity Map of the Fractured Layer}

The iso-resistivity map of the fractured layer is shown in Figure 9. This map showed the distribution in the resistivity of the fractured layer within the study area. It showed that the fractured layer resistivity varies from 10 $\Omega \mathrm{m}$ to less than $290 \Omega \mathrm{m}$. The low resistivity may be indicative of saline water in the aquifer.

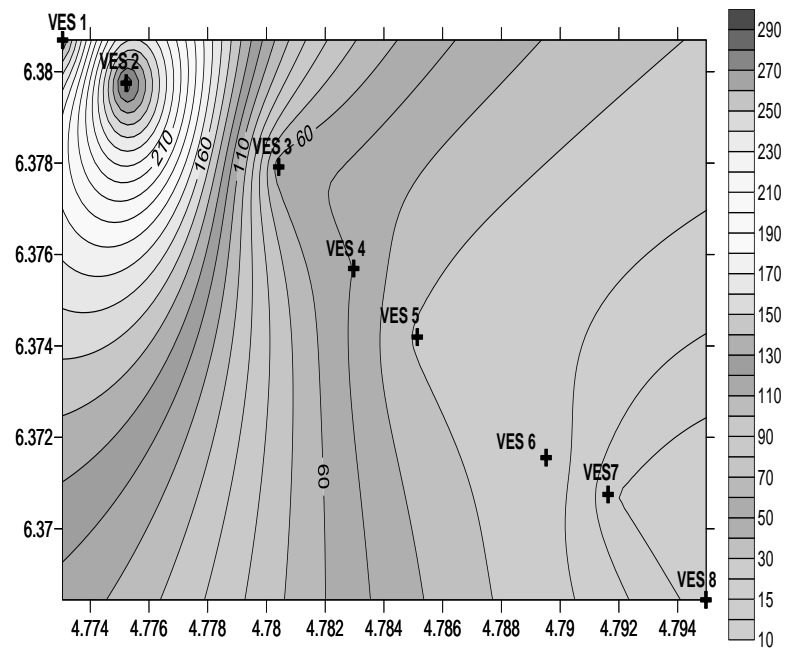

Fig. 9. Isoresistivity map of the fractured layer in the study area.

\subsection{Isopach map of the fractured layer}

This map showed the distribution in the thickness of the fractured layer within the study area (Figure 10). It showed that the thickness of the fractured layer varies from 13 to $37 \mathrm{~m}$. The isopachmap showed that the fractured layer is generally thick $(<40 \mathrm{~m})$.

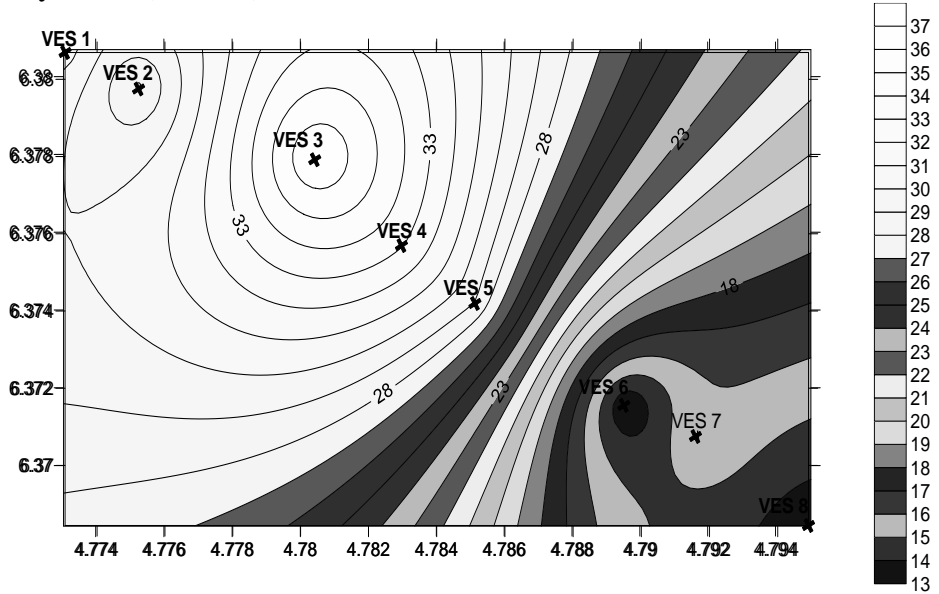

Fig. 10. Isopach Map of the fractured layer. 
Table 2. Average value of the physical parameters of water samples.

\begin{tabular}{|l|c|c|}
\hline Location & $\mathrm{pH}$ & Conductivity $(\mathrm{mS} / \mathrm{m})$ \\
\hline Igbokoda I & 5.96 & 45.00 \\
\hline Igbokoda II & 5.46 & 45.02 \\
\hline Igbokoda III & 6.54 & 198.15 \\
\hline Igbokoda IV & 6.89 & 240.00 \\
\hline Igbokoda V & 6.65 & 156.90 \\
\hline Igbokoda VI & 5.57 & 106.05 \\
\hline Igbokoda VII & 6.98 & 302.00 \\
\hline Igbokoda VIII & 6.76 & 292.00 \\
\hline IS, WHO STD & $\mathbf{6 . 8 - 8 . 5}$ & $\mathbf{5 . 0 0 - 5 0 . 0 0}$ \\
\hline
\end{tabular}

Table 3. Concentration of heavy metals in water samples in $\mathrm{ppm}(\mathrm{mg} / \mathrm{L})$.

\begin{tabular}{|l|c|c|c|c|c|c|c|c|c|}
\hline Parameter & GBK I & GBK II & $\begin{array}{c}\text { GBK } \\
\text { III }\end{array}$ & $\begin{array}{c}\text { GBK } \\
\text { IV }\end{array}$ & GBK V & $\begin{array}{c}\text { GBK } \\
\text { VI }\end{array}$ & $\begin{array}{c}\text { GBK } \\
\text { VII }\end{array}$ & $\begin{array}{c}\text { GBK } \\
\text { VIII }\end{array}$ & $\begin{array}{c}\text { WHO } \\
\text { STD(2008) }\end{array}$ \\
\hline Zn & 0.04 & 0.05 & 0.02 & 0.03 & 0.04 & 0.02 & 0.03 & 0.02 & 5.0 \\
\hline Cd & 0.10 & 0.11 & 0.09 & 0.10 & 0.12 & 0.11 & 0.09 & 0.10 & 0.01 \\
\hline $\mathbf{M g}$ & 2.25 & 2.09 & 1.64 & 3.35 & 1.41 & 0.89 & 2.78 & 1.72 & $10-100$ \\
\hline$\underline{\text { Mn }}$ & 0.13 & 0.05 & 0.05 & $\underline{\text { BDL }}$ & $\underline{\text { BDL }}$ & $\underline{\text { BDL }}$ & $\underline{\text { BDL }}$ & $\underline{\text { BDL }}$ & 0.1 \\
\hline
\end{tabular}

Note: BDL - Below Detection Level; GBK- IGBOKODA

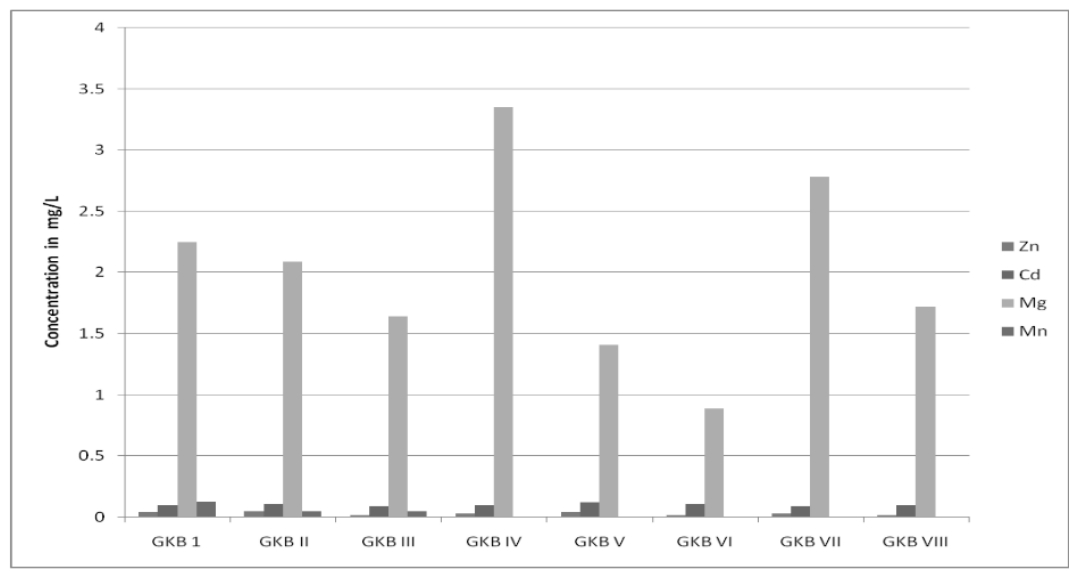

Fig. 11. Concentration of heavy metals in water samples.

\subsection{Sample Analyses}

Water samples analysed for chemical constituents and trace elements revealed that the water samples has not exceeded a [20], drinking-water standard, although the physical properties for instance, the electrical conductivity for six out of the eight zones have conductivities above the standard limit. The concentrations of Zinc (Zn), Cadmium (Cd), Magnesium (Mg), obtained are in the following range 0.02- 0.05 mg/L; $0.09-0.12$ $\mathrm{mg} / \mathrm{L} ; 0.89-2.28 \mathrm{mg} / \mathrm{L}$ respectively and Manganese $(\mathrm{Mn}) 0.05-0.13 \mathrm{mg} / \mathrm{L}$ to BDL. The concentrations of all metals within the study area are at least within the permissible limit (Table 3). Figure 11 is a pictorial representation of the elements detected in the region. The $\mathrm{pH}$ ranges between 5.46 and 6.98 . The $\mathrm{pH}$ is slightly out of the limit of [21] WHO standard $(6.8-8.5)$. This is an indication that the water is in acid domain. Also, from the observed $\mathrm{pH}$ values depicts increasing electrical conductivity (EC) from landward aquifers towards the lagoon, a situation that suggests the influence of lagoon water salinity through gradual encroachment into the coastal aquifers as evidenced by the result. The lagoon recharges the aquifers and since its water is saline, therefore the invaded aquifers become more conductive. Similar conductivity (inverse of resistivity) flow paths from the water body to the coastal aquifers were equally noticed in the VES survey (VES 3, 4, 5, 6, 7 and 8).

The conductivity value within the study area is $45.00 \mathrm{mS} / \mathrm{m}$ to $302.00 \mathrm{mS} / \mathrm{m}$. The area where conductivity is of low value $(45.00-45.02 \mathrm{mS} / \mathrm{m})$ implied region of non-intrusion of saltwater, that is areas of Igbokoda I and II, see Table 2. This is further shown in Figure 12. The region where conductivity ranges from $106.00-302.00$ $\mathrm{mS} / \mathrm{m}$ depicts region of saltwater intrusion into the freshwater aquifers. 


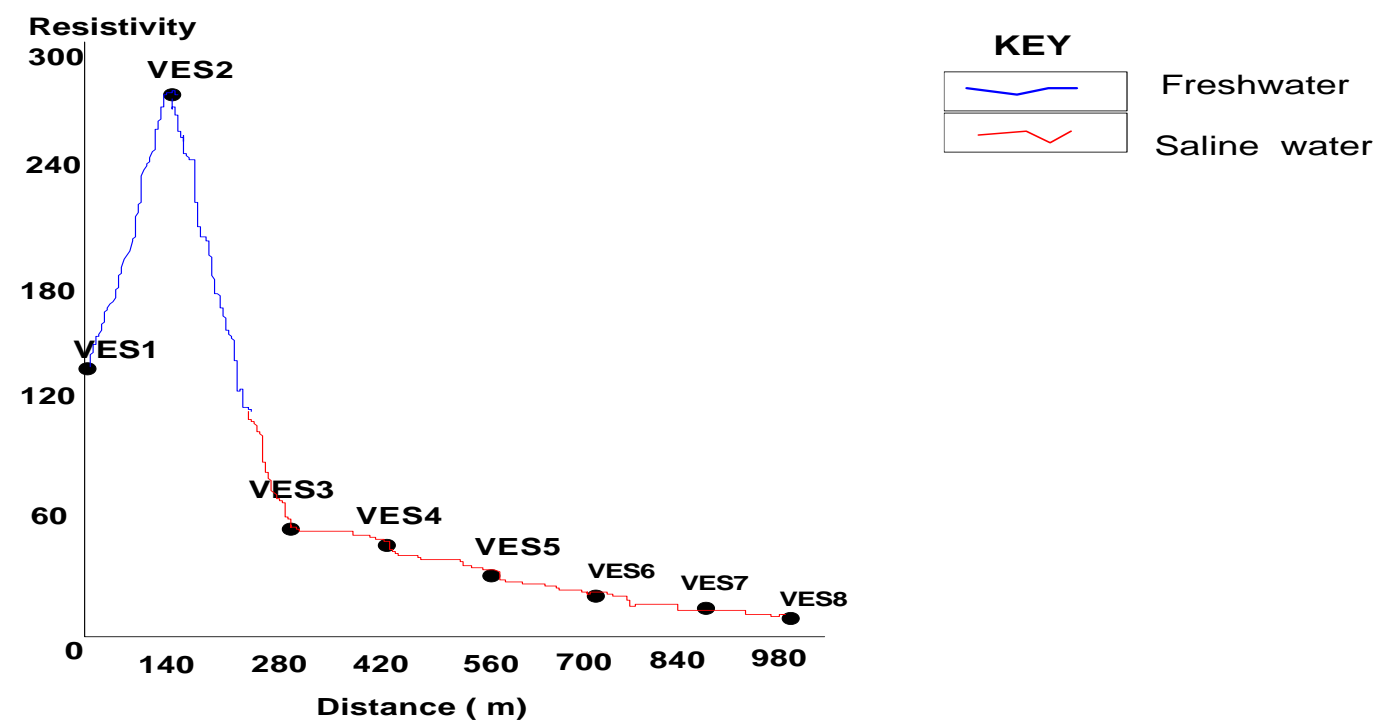

Fig. 12. Resistivity profiles showing the low resistivity zones caused by saline contamination.

\section{CONCLUSION}

Geophysical and Chemical investigation was carried out at Igbokoda area of Ilaje, Ondo State Southwestern, Nigeria with the aim of mapping out saltwater intruded area. It was deduced from the results of the Vertical Electrical Sounding that the area is characterized by $\mathrm{K}$ and $\mathrm{KH}$ curve types with the KH-type predominant. Four geoelectric layers were delineated within the study area which includes: the topsoil, the weathered layer, fractured basement and the fresh basement rock with resistivity values of the topsoil $(67.6 \Omega \mathrm{m}-314.3 \Omega \mathrm{m})$ having thickness range $0.3 \mathrm{~m}-2.3 \mathrm{~m}$. At the weathered layer the thickness ranging from $2.7 \mathrm{~m}$ to $19.3 \mathrm{~m}$ and resistivity varies from $(490.8 \Omega \mathrm{m}-1912.7 \Omega \mathrm{m})$ proves to be the freshwater horizon. The fractured basement having thickness range of $27.8 \mathrm{~m}-37.1 \mathrm{~m}$ have been invaded by saline water $(11.7 \Omega \mathrm{m}-54 \Omega \mathrm{m})$.

Based on the result obtained from geophysical data and chemical analyses, it can be concluded that water from Igbokoda I (VES 1) and Igbokoda II (VES 2) are freshwater (good for drinking and domestic use) based on the fact that their concentration levels of heavy metals (was below the recommended level), conductivity and resistivity meet drinking water standard. However, problems can arise due to bioaccumulation in the human tissues over a long period of time. Saline/brackish water intrusion was mapped out under VES3-VES8 close to the water. The water bodies from Igbokoda III to Igbokoda VIII (VES 3 -VES8) as we moved $280 \mathrm{~m}$ away from the landward to seaward, were found to be contaminated by saltwater, which is generally unsafe for domestic, industrial and agricultural uses.

\section{REFERENCES}

[1] General Interest Publications of the U.S. Gelogical Survey, Branch of Information Services, 2017. On line: infoservices@usgs.gov.

[2] Post, V., Abarca, E., Saltwater and freshwater interaction in coastal aquifers, Hydrogeology Journal, vol. 18, 2009, p. 1-4.

[3] Ranjan, P., Effect of climate change and land use change on saltwater intrusion, 2007.

[4] Reilly, T.E., Goodman, A.S., Quantitative analysis of saltwater - supply paper, vol. 2176, 1985, p. 30.

[5] Glover, R. E., The pattern of freshwater flow in a coastal aquifer, Journal of Geophysical Research, vol. 64, no. 4, 1959, p. 457-459.

[6] Loke, M.H., Tutorial: 2-D and 3-D Electrical Imaging Surveys. Revised Edition, 2004, p. 136. On line: http://www.gps.caltech.edu/classes/ge111/Docs/DCResistivity_Notes.pdf.

[7] Sorensen, K.I., Auken, E., Christensen, N., Pellerin, L., An integrated approach for hydrogeophysical investigations: New technologies and a case history, In: Bulter D. K., Near-surface Geophysics. Tulsa, USA, Society of Exploration Geophysicists, 2005, p. 585-597.

[8] Ekinci, Y.L., Demirci, A., Ertekin, C., Investigation of the layered seawater- freshwater interface: A study from Kalekoy-Gokceada, Turkey, International earthquake symposium Kocaeli, 2007, p. 225-229. 
[9] Atakpo, E.A., Ayolabi, E.A., Evaluation of aquifer vulnerability and the protective capacity in some oil producing communities of western Niger Delta, Environmentalist, no. 29, 2009, p. 310-317.

[10] Gemail, K.S., El-Shishtawy, A.M., El-Alfy, M., Ghoneim, M.F., Abd El-Bary, M.H., Assessment of aquifer vulnerability to industrial waste water using resistivity measurements: A case study along El-Gharbyia main drain, Nile Delta, Egypt. Journal Applied Geophysics, vol. 75, 2011, p. 140-150.

[11] Vaudelet, P., Schmutz, M., Pessel, M., Franceschi, M., Guerin, R., Atteia, O., Blondel, A., Ngomseu, C., Galaup, S., Rejiba, F., Begassat, P. Mapping of contaminant plumes with geoelectrical methods: a case study in urban context, Journal Appllied Geophysics, no. 75, 2011, p. 738-751.

[12] Talabi, A.O., Ademilua, O.L., Ajayi, O.Z., Ogunniyi, S.O., Preliminary geophysical evaluation of orin bauxite deposit Southwestern Nigeria. J. Emerg. Trends Eng. Applied Science, vol. 4, 2013, p. 432-437.

[13] Rahaman, M.A., Recent advances in the study of the basement complex of Nigeria, P.O. Oluyide (Coordinator), Precambrian Geology of Nigeria, Geological Survey, Nigeria, 1988.

[14] Rahaman, M.A., Review of the basement geology of Southwestern Nigeria, Geology of Nigeria, Kogbe, C.A. Elizabethan publishing, Lagos, Nigeria, 1976.

[15] Loke, M.H., Barker, R.D., Rapid least-squares inversion of apparent resistivity pseudosections by a QuasiNewton method, Geophys prospect, no. 44, 1996, p. 131-152.

[16] Keller, G.V., Frischknecht, F.C., Electrical Methods in Geophysical Prospecting, Oxford: Pergamon. Lowcontaminated site, Water research, no. 37, vol. 5, 1966, p. 959-964.

[17] Vander Velpen B.P.A, 1988, RESIST Software Version 1.0. M, Sc Research Project, TC, Delft, Netherlands, ITC, IT-RSG/DSG, 2004.

[18] Ayolabi, E.A., Adetayo, FF., Abiodun, M.O., Adelere, E.A., Mapping saline water intrusion into the coastal aquifer with geophysical and geochemical techniques: the University of Lagos campus case (Nigeria) Sprigerplus, vol. 2, 2013, p. 433.

[19] Igroufa, S., Hashim, R., Taib, S., Mapping of Salt-water intrusion by Geoelectrical Imaging in Carey Island, 5th International symposium on hydrocarbons \& chemistry (ISHC5), Sidi Fredj, Algiers, 2010.

[20] USEPA (U.S. Environmental Protection Agency), Drinking Water Standard, 2009.

[21] WHO, Guidelines 